Article

\title{
Synthesis, Characterization, and Anticancer Activity of Benzothiazole Aniline Derivatives and Their Platinum (II) Complexes as New Chemotherapy Agents
}

\author{
Md. Kamrul Islam ${ }^{1}{ }^{(}$, Ah-Rum Baek ${ }^{2}$, Bokyung Sung ${ }^{2}$, Byeong-Woo Yang ${ }^{2}$, Garam Choi ${ }^{3}$, Hyun-Jin Park ${ }^{3}$, \\ Yeoun-Hee Kim ${ }^{3}{ }^{1}$, Minsup Kim ${ }^{4}$, Seongmin $\mathrm{Ha}^{5}$, Gang-Ho Lee ${ }^{6}$, Hee-Kyung Kim ${ }^{7, *}$ and Yongmin Chang ${ }^{2,8,9, *}$ \\ 1 Institute of Biomedical Engineering Research, Kyungpook National University, 680, Gukchaebosang-ro, \\ Jung-gu, Daegu 41944, Korea; mkislam2008@yahoo.com \\ 2 Department of Medical \& Biological Engineering, Kyungpook National University, 80, Daehak-ro, Buk-gu, \\ Daegu 41566, Korea; baxun@naver.com (A.-R.B.); xxgzxz4@naver.com (B.S.); \\ byungwoo1128@naver.com (B.-W.Y.) \\ 3 R\&D Center, Mirae BioPharm. Co., 124, Sagimakgol-ro, Jungwon-gu, Seongnam-si 13207, Korea; \\ garam1458@naver.com (G.C.); phj0808@naver.com (H.-J.P.); bigeye38@naver.com (Y.-H.K.) \\ 4 InCerebro Drug Discovery Institute, Seoul 01811, Korea; minsupkim.bio@gmail.com \\ 5 Department of Biomedical Science, School of Medicine, Kyungpook National University, 680, \\ Gukchaebosang-ro, Jung-gu, Daegu 41944, Korea; zx996574@gmail.com \\ 6 Department of Chemistry, Kyungpook National University, 80, Daehak-ro, Buk-gu, Daegu 41566, Korea; \\ ghlee@knu.ac.kr \\ check for \\ updates \\ Citation: Islam, M.K.; Baek, A.-R.; \\ Sung, B.; Yang, B.-W.; Choi, G.; Park, \\ H.-J.; Kim, Y.-H.; Kim, M.; Ha, S.; Lee, \\ G.-H.; et al. Synthesis, \\ 7 Laboratory Animal Center, the Daegu-Gyeongbuk Medical Innovation Foundation, 88 Dongnae-ro, Dong-gu, \\ Daegu 41061, Korea \\ 8 Department of Molecular Medicine, School of Medicine, Kyungpook National University, 680, \\ Gukchaebosang-ro, Jung-gu, Daegu 41944, Korea \\ 9 Department of Radiology, Kyungpook National University Hospital, 130 Dongdeok-ro, Jung-gu, \\ Daegu 41944, Korea \\ * $\quad$ Correspondence: hkkim@dgmif.re.kr (H.-K.K.); ychang@knu.ac.kr (Y.C.); Tel.: +82-53-420-5471 (Y.C.)
}

Characterization, and Anticancer Activity of Benzothiazole Aniline Derivatives and Their Platinum (II) Complexes as New Chemotherapy Agents. Pharmaceuticals 2021, 14, 832. https://doi.org/10.3390/ph14080832

Academic Editor: Luís M. T. Frija

Received: 30 July 2021

Accepted: 21 August 2021

Published: 23 August 2021

Publisher's Note: MDPI stays neutral with regard to jurisdictional claims in published maps and institutional affiliations.

Copyright: (c) 2021 by the authors. Licensee MDPI, Basel, Switzerland. This article is an open access article distributed under the terms and conditions of the Creative Commons Attribution (CC BY) license (https:// creativecommons.org/licenses/by/ $4.0 /)$.

\begin{abstract}
We describe the synthesis, characterization, molecular modeling, and in vitro anticancer activity of three benzothiazole aniline (BTA) ligands and their corresponding platinum (II) complexes. We designed the compounds based on the selective antitumor properties of BTA, along with three types of metallic centers, aiming to take advantage of the distinctive and synergistic activity of the complexes to develop anticancer agents. The compounds were characterized using nuclear magnetic resonance spectrometry, Fourier transform infrared spectroscopy, mass spectrometry, elemental analysis, and tested for antiproliferative activity against multiple normal and cancerous cell lines. L1, L2, and L1Pt had better cytotoxicity in the liver, breast, lung, prostate, kidney, and brain cells than clinically used cisplatin. Especially, L1 and L1Pt demonstrated selective inhibitory activities against liver cancer cells. Therefore, these compounds can be a promising alternative to the present chemotherapy drugs.
\end{abstract}

Keywords: benzothiazole aniline (BTA); platinum (II); anticancer; DNA; liver; docking

\section{Introduction}

The success of cisplatin [cis-diamminedichloroplatinum-(II)] flagged the way for second-and third-generation cancer drugs: carboplatin, oxaliplatin, nedaplatin, and lobaplatin (Figure 1) [1-3]. The efficacy of cisplatin is governed by its ability to covalently bind with DNA and change its helical structure, resulting in cell death [4]. However, new anticancer agents have drawn attention for the reason that current platinum agents present drug resistance and have several limitations, such as a lack of selectivity, poor pharmacokinetic profiles and inadequate water solubility [5-8]. Moreover, existing platinum-based chemotherapy drugs are mostly correlated with general toxicity, which causes adverse 
side effects [9-13]. An additional change to cisplatin may regulate these toxic effects. For instance, the substitution of the amine group in cisplatin using 1,2-ethylenediamine forms a structure that is used in various structure-activity relationship (SAR) studies, and proper substitution of the ethane bridge by aromatic groups may increase the cytotoxicity [14-17]. As well, pyridine moiety was also used in several Pt chemotherapeutics, which have shown promising antiproliferative properties [18,19].

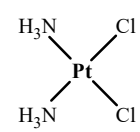

Cisplatin

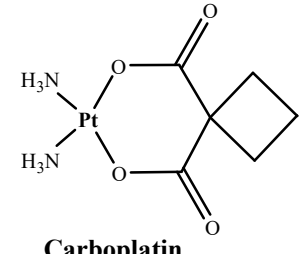

Carboplatin<smiles>O=C1O[PH]2(NC3CCCCC3N2)OC1=O</smiles>

Oxaliplatin<smiles>N[P+]1(N)OCC(=O)O1</smiles>

Nedaplatin

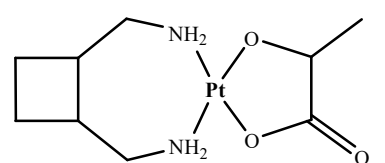

Lobaplatin

Figure 1. Structure of the clinically approved platinum complexes.

Benzothiazole aniline (BTA), which is chemically known as 2-(4-aminophenyl)-benzothiazole, is a fused heterocyclic pharmacophore that exhibits antitumor activity [20]. Substituent exchange of the $3^{\prime}$-position with methyl or halogens (for instance $\mathrm{Cl}$ ) contributes to the increased antitumor activity against various cancer cell lines (ovarian, colon, renal, etc.) [21,22]. Moreover, BTA showed selective anticancer activity by demonstrating a distinct cytotoxic response against some tumor cell lines, while no hormonal dependency was recognized $[23,24]$. Therefore, several studies have been performed in the past years to develop novel BTA derivatives as anticancer agents [25-28]. For example, the ring-substituted BTA derivative 2-(4-amino-3-methylphenyl) benzothiazole-DF 203-was developed as an antitumor agent, and phortress NSC 710,305 underwent phase 1 clinical trials as a prodrug [24,25]. In addition, technium $\left({ }^{99 \mathrm{~m}} \mathrm{Tc}\right)$ and rhenium $\left({ }^{186} \mathrm{Re},{ }^{188} \mathrm{Re}\right)$ complexes of BTA conjugate were developed as radiopharmaceuticals for targeted therapy and imaging of breast cancer [29,30]. In our previous study, we developed a bifunctional Gd-DO3A-BTA chelate and evaluated its antiproliferative activity, both in vivo and in vitro, as a theranostic agent [31]. Recently, Mavroidi et al. synthesized Pd (II) and Pt (II) chelates of BTA derivatives to target cancer cells, however, the studied compounds proved less cytotoxic than clinically permitted cisplatin [32]. The approach using different types of biologically active moieties is frequently used in the design of novel metal-based drugs [33-35]. For example, a series of biologically active organometallic compounds were synthesized bearing an acetylsalicylic acid (ASA) substructure to inhibit cyclooxygenase (COX) enzymes [36]. Also, the nonsteroidal anti-inflammatory drug was conjugated to $\mathrm{Pt}$ (II) with various intracellularly cleavable linkers, which disclosed potent cytotoxic activity against different cancer cell lines [37]. Similarly, few novel Pt (II) complexes were synthesized bearing aliphatic amines and 1,8-naphthalimide moieties with DNA-targeting properties to achieve more potent and selective metallodrugs [38].

Based on the concepts containing biologically active molecules and the cisplatin-like composite, we designed and synthesized novel benzothiazole aniline derivatives (L1, L2, and L3) and their corresponding Pt (II) complexes as selective agents for treating cancer. We have hypothesized that the conjugation of new ligands using BTA will result in compounds that have distinct cytotoxic properties as BTA is well known for its antitumor activity. In vitro screening was performed in different cancer and normal cell lines, and stability of the lead compounds was measured in buffered aqueous solution. In addition, we 
conducted molecular modeling studies to predict the best binding poses of ligands in the active site of DNA. We hypothesized that L1 and L1Pt can be promising candidates for treating liver, colon, breast, prostate, cervical, and brain cancers.

\section{Results and Discussion}

\subsection{Synthesis and Characterization}

The syntheses of the BTA derivatives L1, L2, and L3 and their Pt (II) complexes L1Pt, $\mathbf{L 2 P t}$, and $\mathbf{L 3 P t}$ are depicted in Scheme 1. Compound $\mathbf{L} 1$ was derived based on our previously published procedure [39], which was then condensed with two salicylaldehyde equivalents to give the $\mathbf{L} 2$ ligand (white solid). The reaction of $\mathbf{L} \mathbf{1}$ with 2-pyridinecarboxaldehyde at room temperature in the presence of $\mathrm{N}$-bromosuccinamide resulted in $\mathbf{L} 3$ (as a yellow solid). Platinum complexes L1Pt, L2Pt, and $\mathbf{L 3 P t}$ were prepared by reacting the respective ligands L1, L2, and $\mathbf{L} 3$ with an equivalent of $\mathrm{K}_{2} \mathrm{PtCl}_{4}$ under inert conditions. Potassium carbonate $\left(\mathrm{K}_{2} \mathrm{CO}_{3}\right)$ was used to increase the reaction rate of complex L2Pt. The pure Pt (II) chelates were isolated in moderate yield after washing repeatedly with water, methanol and ether. The formation of the ligands and their $\mathrm{Pt}$ (II) complexes were confirmed using various spectroscopic methods such as ${ }^{1} \mathrm{H}$ nuclear magnetic resonance (NMR), ${ }^{195} \mathrm{Pt}-\mathrm{NMR}$, Fourier transform infrared spectroscopy (FTIR), high-resolution fast atom bombardment mass spectrometry (HR-FAB-MS), matrix-assisted laser desorption/ionization time-offlight mass spectrometry (MALDI-TOF-MS), and elemental analysis (EA).<smiles>NCC(N)C(=O)OCCCCC(=O)O</smiles><smiles>CC(C)(C)OC(=O)NCC(NC(=O)OC(C)(C)C)C(=O)O</smiles>

1

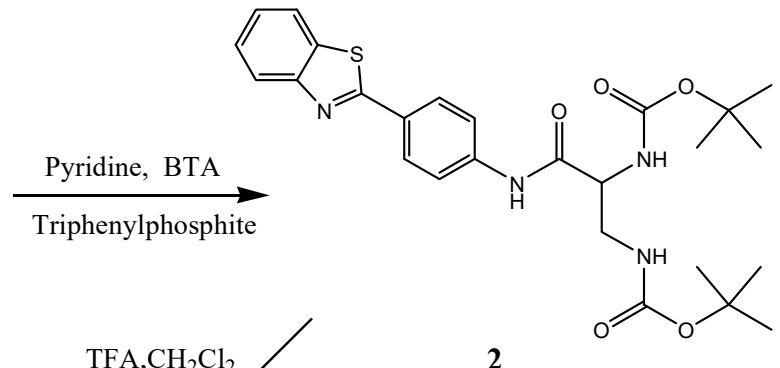

2

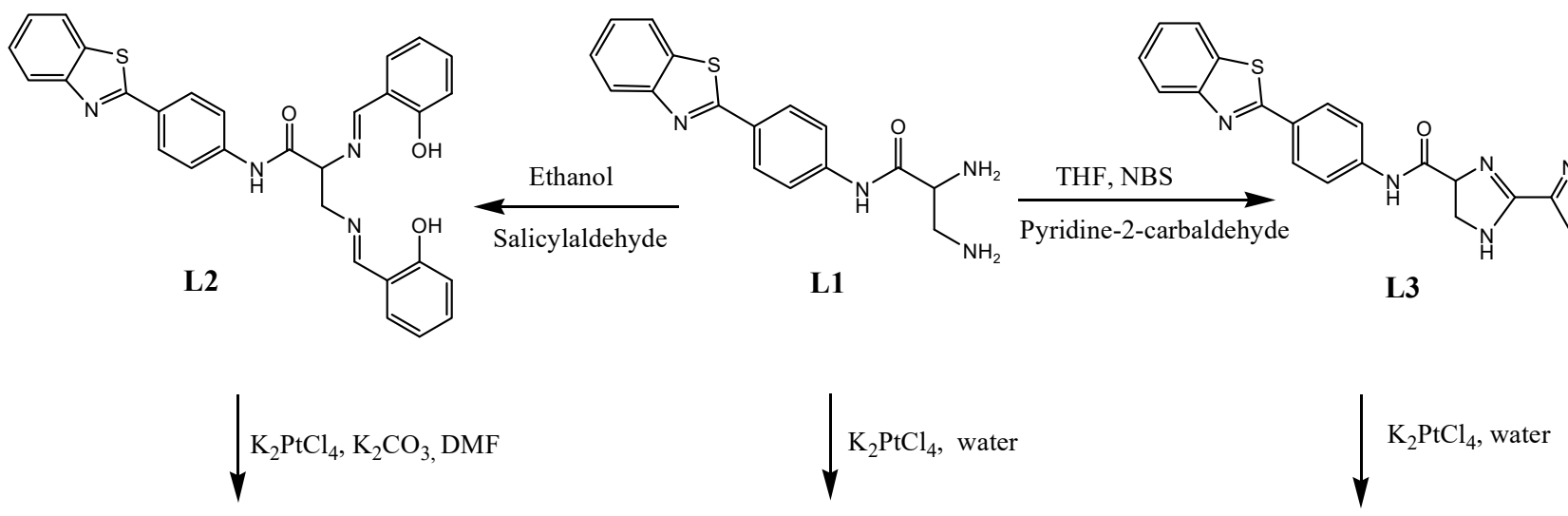<smiles></smiles><smiles>O=C(Nc1ccc(-c2nc3ccccc3s2)cc1)C1CN[Te](Cl)(Cl)N1</smiles>

L1Pt

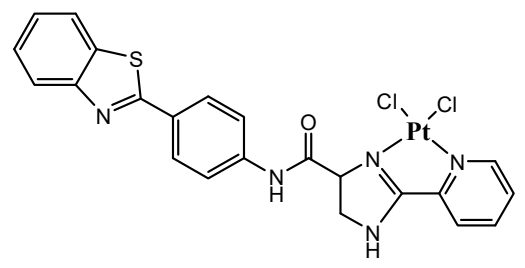

L3Pt

Scheme 1. Synthesis of the benzothiazole aniline (BTA) derivatives and their platinum (II) complexes. 
${ }^{1} \mathrm{H}-\mathrm{NMR}$ spectra of the newly synthesized ligands L1, L2, and L3 and their Pt complexes $\mathbf{L 1 P t}$, L2Pt, and $\mathbf{L 3 P t}$ were recorded in different solvents, such as $\mathrm{MeOH}-\mathrm{d}_{4}, \mathrm{CHCl}_{3}$, DMSO- $\mathrm{d}_{6}$, and the details are presented in the experimental section. The ${ }^{1} \mathrm{H}-\mathrm{NMR}$ spectral data are consistent with the expected structure of the compounds (Supporting Information Figures S1, S4, S6, S9 and S12). In addition, complex L1Pt was characterized using ${ }^{195} \mathrm{Pt}-\mathrm{NMR}$ and the chemical shifts $\left(\delta=-2955 \mathrm{ppm}, \mathrm{DMSO}-\mathrm{d}_{6}\right)$, indicated no inter- or intramolecular contacts between the Pt (II) center and BTA moieties (Supporting Information Figure S7) [40]. The formation of $\mathbf{L} 2$ was confirmed by the presence of a $\mathrm{C}=\mathrm{N}$ stretching vibration at $1634 \mathrm{~cm}^{-1}$ and the coordination of the metal center was confirmed by the downshift of $\mathrm{C}=\mathrm{N}$ at $1600 \mathrm{~cm}^{-1}$ due to the development of Ar-O-Pt-N=CH-chelating ring and loss of salicylic effect [41]. The FTIR spectrum of L2 compared well to that of the corresponding L2Pt complex (Supporting Information Figures S3 and S10) Therefore, the ${ }^{1} \mathrm{H}-\mathrm{NMR},{ }^{195} \mathrm{Pt}-\mathrm{NMR}$, and FTIR analysis data showed that the complexation of the ligand L1 and L2 with Pt was accomplished by coordination using amine and/or Schiff-bases nitrogen. In addition, high-resolution mass spectrometry in positive-ion mode was performed for all synthesized compounds. Parent peaks were found at $(\mathrm{m} / \mathrm{z}) 578,(\mathrm{~m} / \mathrm{z}) 714$, and $(m / z) 687$ for complexes L1Pt, L2Pt, and L3Pt (Supporting Information Figures S8, S11 and S13). Ion peaks corresponding to the ligands have been observed at $(\mathrm{m} / \mathrm{z}) 313,(\mathrm{~m} / \mathrm{z})$ 521, and $(\mathrm{m} / \mathrm{z}) 400$ for L1, L2, and L3 (Supporting Information Figures S2 and S5) [39]. The purity of the newly synthesized compounds was confirmed by EA. L1 was soluble in water and all other compounds when dissolved in DMSO.

\subsection{Anticancer Effects and Cytotoxicity}

We have tested the effects of different concentrations of ligands L1, L2, and L3 and their platinum complexes L1Pt, L2Pt, and L3Pt on the viability of various cancerous and normal cell lines (Tables 1 and 2, Figure 2). The half-inhibitory concentration $\left(\mathrm{IC}_{50}\right)$ values were calculated based on these data. The data showed that each component inhibits the growth of different cell lines at varying degrees. L1, L1Pt, and L2 exhibit similar cytotoxicity to that of cisplatin and BTA used as a control group in HeLa cells (Table 1 and Figure 2A). However, L1, L1Pt, and L2 exhibited excellent toxicity to most of the cancer cells, except for HeLa cells. The L1 and L1Pt exerted the best efficacy in liver and colon cancer cells. In addition, L2Pt revealed the anticancer effect only in liver cancer cells, and L3 had the possibility of the anticancer effect in glioma and prostate cancer cells. Although $\mathbf{L} 3$ induced a better anticancer effect than BTA in colon cancer cells, it did not reach the effect of cisplatin. L3Pt did not show anticancer effects in the tested cell lines, and the reason needs clarification. The structure-activity reveals that the conjugation of the 1,2-ethylenediamine with BTA (L1 and L1Pt) exhibited excellent inhibitory activity against numerous cancer cells. Moreover, the exchange of the ethylene bridge with electron-donating hydroxyl group-containing phenol rings (i.e., compounds $\mathbf{L} 2$ and L2Pt) displayed better anticancer activity than those of pyridine-containing derivatives L3 and L2Pt. From toxicity comparison in normal cells (Table 2 and Figure 2B), we confirmed that the toxicity of L1, L1Pt, and L2 was improved more than the cisplatin in the liver and brain cells. Although L2Pt, L3, and L3Pt did not exhibit toxicity in most of the normal cell lines, they did not display any anticancer effects, therefore, these compounds are not considered for further study. 


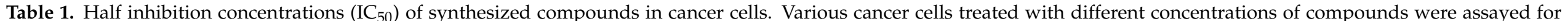

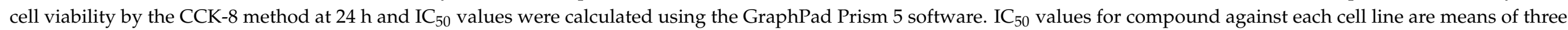
independent experiments [ $n=3$, mean \pm SEM (standard error of mean)]. Cisplatin and BTA, which are the backbones of the compounds, were compared as positive controls.

\begin{tabular}{|c|c|c|c|c|c|c|c|c|c|}
\hline \multirow{2}{*}{$\begin{array}{l}\text { Tissue } \\
\text { Sources }\end{array}$} & \multirow{2}{*}{$\begin{array}{c}\text { Cell } \\
\text { Lines }\end{array}$} & \multicolumn{8}{|c|}{$\mathrm{IC}_{50}(\mu \mathrm{M})$ for } \\
\hline & & Cisplatin & BTA & L1 & L1Pt & L2 & L2Pt & L3 & L3Pt \\
\hline Human lung cancer & A549 & $>500$ & $>500$ & $100.16 \pm 8.4$ & $167.2 \pm 11.2$ & $182.4 \pm 0.8$ & $>500$ & $>500$ & $>500$ \\
\hline Human renal cancer & Caki-2 & $>500$ & $462.8 \pm 44.1$ & $75.6 \pm 3.4$ & $105.7 \pm 8.5$ & $159.0 \pm 4.3$ & $>500$ & $>500$ & $>500$ \\
\hline Human cervical cancer & HeLa & $26.2 \pm 5.6$ & $76.4 \pm 23.4$ & $41.9 \pm 3.4$ & $64.7 \pm 0.3$ & $47.0 \pm 6.0$ & $221.0 \pm 15.8$ & $98.9 \pm 3.5$ & $>500$ \\
\hline Human hepatic carcinoma & HepG2 & $54.2 \pm 31.8$ & $52.0 \pm 5.7$ & $5.9 \pm 0.5$ & $7.5 \pm 0.1$ & $14.2 \pm 7.0$ & $31.6 \pm 3.6$ & $>500$ & $>500$ \\
\hline Human colon cancer & HT-29 & $39.1 \pm 0.6$ & $275.3 \pm 5.0$ & $29.9 \pm 0.3$ & $42.6 \pm 5.6$ & $135.0 \pm 4.4$ & $172.6 \pm 3.2$ & $70.5 \pm 0.2$ & $>500$ \\
\hline Human breast cancer & MCF-7 & $203.8 \pm 27.3$ & $103.9 \pm 28.6$ & $65.9 \pm 12.3$ & $59.0 \pm 11.0$ & $98.1 \pm 7.9$ & $>500$ & $190.3 \pm 16.5$ & $>500$ \\
\hline Human prostate cancer & PC-3 & $>500$ & $181.7 \pm 7.8$ & $94.9 \pm 0.8$ & $55.7 \pm 7.5$ & $116.3 \pm 5.0$ & $>500$ & $130.2 \pm 34.7$ & $>500$ \\
\hline
\end{tabular}

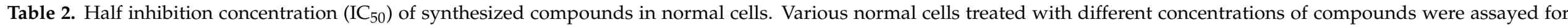

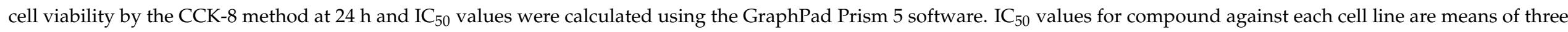
independent experiments $(n=3$, mean \pm SEM). Cisplatin and BTA, which are the backbones of the compounds, were compared as positive controls.

\begin{tabular}{|c|c|c|c|c|c|c|c|c|c|}
\hline \multirow{2}{*}{$\begin{array}{c}\text { Tissue } \\
\text { Sources }\end{array}$} & \multirow{2}{*}{$\begin{array}{c}\text { Cell } \\
\text { Lines }\end{array}$} & \multicolumn{8}{|c|}{$\mathrm{IC}_{50}(\mu \mathrm{M})$ for } \\
\hline & & Cisplatin & BTA & L1 & L1Pt & L2 & L2Pt & L3 & L3Pt \\
\hline $\begin{array}{l}\text { Mouse liver } \\
\text { hepatocyte }\end{array}$ & AML12 & $32.1 \pm 4.4$ & $>500$ & $137.6 \pm 24.1$ & $139.0 \pm 0.8$ & $>500$ & $>500$ & $>500$ & $>500$ \\
\hline $\begin{array}{c}\text { Human colon } \\
\text { epithelial }\end{array}$ & FHC & $>500$ & $>500$ & $72.7 \pm 2.0$ & $64.3 \pm 2.4$ & $189.2 \pm 10.3$ & $>500$ & $>500$ & $>500$ \\
\hline Human embryonic kidney & HEK-293 & $65.5 \pm 4.1$ & $>500$ & $68.1 \pm 2.8$ & $54.9 \pm 2.8$ & $138.9 \pm 20.1$ & $211.5 \pm 14.9$ & $>500$ & $205.9 \pm 7.4$ \\
\hline $\begin{array}{c}\text { Human breast } \\
\text { epithelial }\end{array}$ & MCF-10A & $95.9 \pm 6.7$ & $401.4 \pm 136.3$ & $65.1 \pm 1.9$ & $46.9 \pm 5.1$ & $79.3 \pm 25.4$ & $>500$ & $>500$ & $>500$ \\
\hline $\begin{array}{c}\text { Mouse brain } \\
\text { neural stem cell }\end{array}$ & NE-4C & $9.0 \pm 0.3$ & $60.9 \pm 2.9$ & $36.8 \pm 3.7$ & $25.7 \pm 1.7$ & $28.2 \pm 0.1$ & $47.0 \pm 4.1$ & $22.4 \pm 2.4$ & $32.4 \pm 6.0$ \\
\hline
\end{tabular}




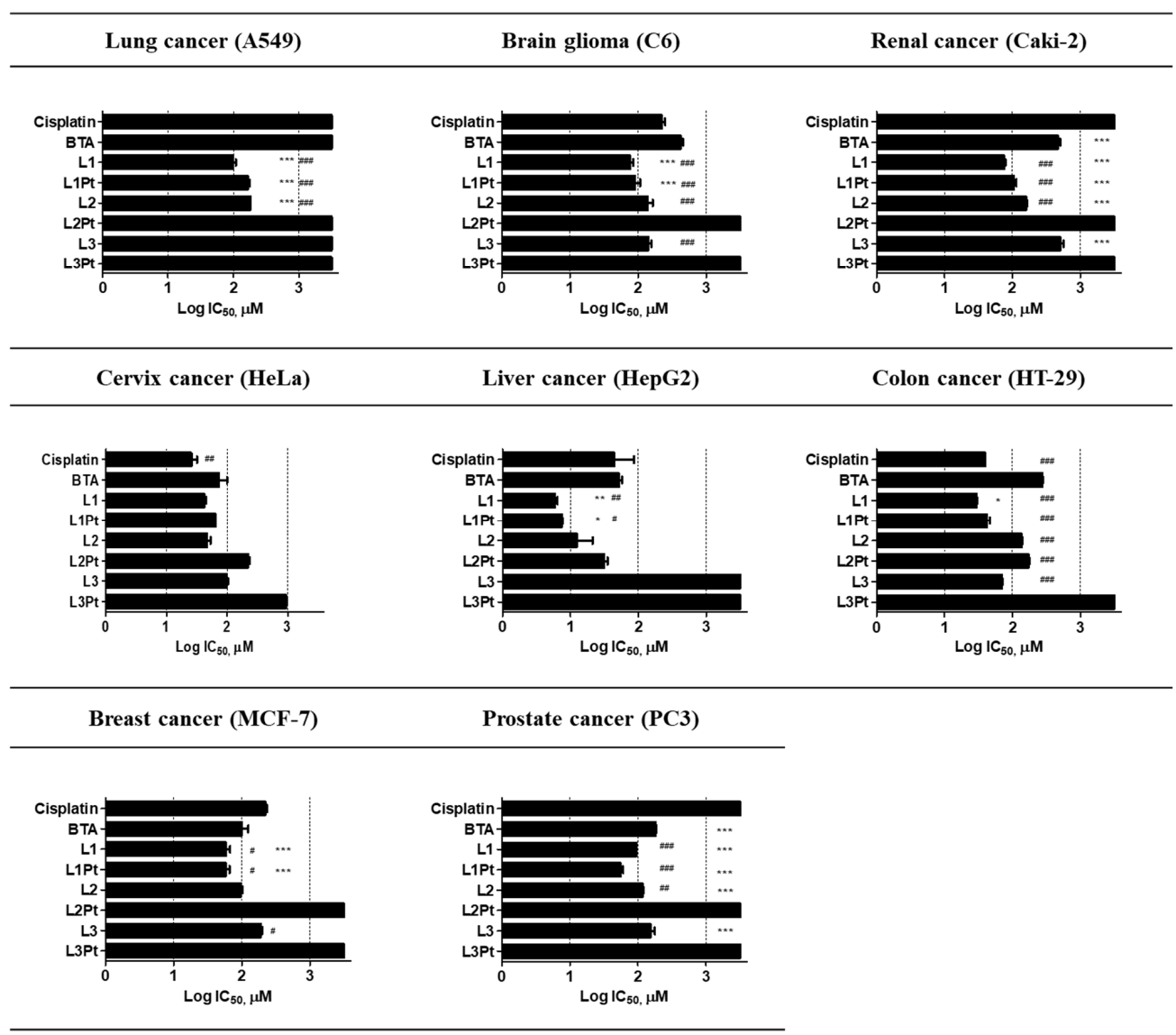

(A)

Normal liver (AML12)

(B)

Figure 2. Toxicity profiles of anti-cancer agents. The graphs show the $\mathrm{Log} \mathrm{IC}_{50}$ for each cytostatic agent in various cell lines. $\mathrm{Log} \mathrm{IC}_{50}$ of at three independent experiments per cell line were averaged and summarized as a mean graph for better comparison of the different activities. (A) It shows the toxicity of synthesized compounds in various cancer cells. (B) It shows the toxicity of synthesized compounds in normal cell lines of various tissues. The red dotted line represents the cisplatin value, and the blue dotted line represents the BTA value. ${ }^{*} p<0.05,{ }^{* *} p<0.01,{ }^{* * *} p<0.001$, significant difference from the cisplatin. \# $p<0.05$, \#\# $p<0.01$, \#\#\# $p<0.001$, significant difference from the BTA. 


\subsection{Selective Antitumor Activity}

A non-malignant mouse liver cell line (AML-12), human colon epithelial cells (FHC), human embryonic kidney cells (HEK-293), human breast epithelial cells (MCF-10A), and mouse brain neural stem-cell line (NE-4C) were used as models of the healthy cells to estimate the selectivity of these compounds in cancer cells regarding normal cells (Table 2, Figure 2B). To correctly term cytotoxicity as "selective" actually, there should be a great difference between tumor and non-tumor cells and it is challenging to compare cytotoxicity from different works. Interestingly, no cytotoxicity was observed for L1, L2, L1Pt, and L2Pt in normal mouse liver hepatocyte cells (AML12) up to $137 \mu \mathrm{M}$ (Table 2). Moreover, compounds L1, L2, L1Pt, and L2Pt displayed an $\mathrm{IC}_{50}$ in liver cancer cells (HepG2) that are $23,35,18.5$, and 15.8 folds higher in comparison with its $\mathrm{IC}_{50}$ value in normal liver cells (AML12) respectively [42]. In contrast, clinically used cisplatin exhibited an $\mathrm{IC}_{50}$ value in normal liver cells (AML12) $32 \mu \mathrm{M}$. In the case of liver cancer cells, L1, L2, L1Pt, and L2Pt showed strong toxicity, while revealed deteriorated toxicity in normal liver cells, demonstrate there is specificity for the liver cancer cells. In addition to liver cancer, L1, L2, L3, and L1Pt showed a more significant anticancer effect than cisplatin or BTA in brain glioma (Table 1). In the toxicity in normal cells, they have significantly improved toxicity than cisplatin in NE-4C cells (Table 2). We observed that compounds L1, L2, L1Pt, and L2Pt exhibited anticancer activity against colon cancer cells. In addition, compound L3 displayed preferential anticancer activity against colon and breast cancer cells. This characteristic anticancer outcome may be attributed to the presence of the BTA moiety, which is well known for its tumor selectivity $[23,24]$. The superior selective toxicity toward cancer cells over noncancer cells proposes a strong potential of these compounds toward their antitumor application in liver cancer.

\subsection{Stability of the Compounds in an Aqueous Solution}

An indispensable feature of any promising anticancer agent is its thermodynamic stability in aqueous media. All prospective agents should be able to reach their target under the conditions encountered in living organisms. Therefore, the stability of the compounds was measured at $1 \mathrm{mM}$ in phosphate-buffered saline (PBS) solution using UVVis spectroscopy. Due to poor solubility in aqueous media, compound L1Pt was dissolved in $2 \%$ DMSO in PBS solution. The stability of the metal complexes is often dependent on the $\mathrm{pH}$ value and the $\mathrm{pH} 4.5-5.0$ is crucial since endosomal uptake of the complexes by lysosomes can occur [43]. Therefore, the UV-Vis spectrum was recorded in the range of 200-450 $\mathrm{nm}$ at $\mathrm{t}=0,7$, and $24 \mathrm{~h}$ in different $\mathrm{pH}$-values [(e.g., strong acidic $(\mathrm{pH}=2)$, weakly acidic $(\mathrm{pH}=5)$, neutral $(\mathrm{pH}=7.4)$, alkaline $(\mathrm{pH}=12)]$. Only the most promising compounds were studied, and Figure 3 represents the time-dependent UV-Vis spectrum of the compound L1 and L1Pt in physiological $\mathrm{pH}$ (7.4). The compounds expressed distinct peaks in the 200-450 nm region and did not display any significant changes throughout $24 \mathrm{~h}$. Lack of substantial interactions in the absorptions peak and spectral characteristics for testing compounds over time propose that no structural alterations occurred in the aqueous solution $[44,45]$. Also, there were no obvious changes in the absorptions peak in other $\mathrm{pH}$-values (such as acidic, weakly acidic, and alkaline) for complexes L1 and L1Pt over time are shown in the Supporting Information (Figure S14).

\subsection{Protein-Ligand Docking Simulation}

The anticancer mechanism of platinum drugs involves their intercalation with DNA base pairs $[46,47]$. Thus, molecular docking studies were conducted to predict the binding poses of ligands in the active site of the DNA. Table 3 shows the docking binding energies of L1, L1Pt, and BTA with various DNA structures. The top-ranked binding energies $(\mathrm{kcal} / \mathrm{mol})$ in the Auto Dock output file were considered a response in every single run. The best docking result was considered with the lowest binding energy of the conformation. The predicted binding energies of compound L1 and L1Pt were -6.697 and $-7.150 \mathrm{kcal} / \mathrm{mol}$, respectively, for binding to the $1 \mathrm{BNA}$, whereas it was $-6.658 \mathrm{kcal} / \mathrm{mol}$ for the parent 
compound BTA. Therefore, this negative binding energy suggests that those compounds rationally bind to DNA as their anticancer target. In addition, compounds L1 and L1Pt with high cytotoxic activity also showed elevated binding energies, -5.839 and $-5.695 \mathrm{kcal} / \mathrm{mol}$, in binding to 3CO3, respectively. Compounds L1 and L1Pt showed lower docking binding energy to DNA in binding to 1LU5 compared with parent BTA.

pH 7.4

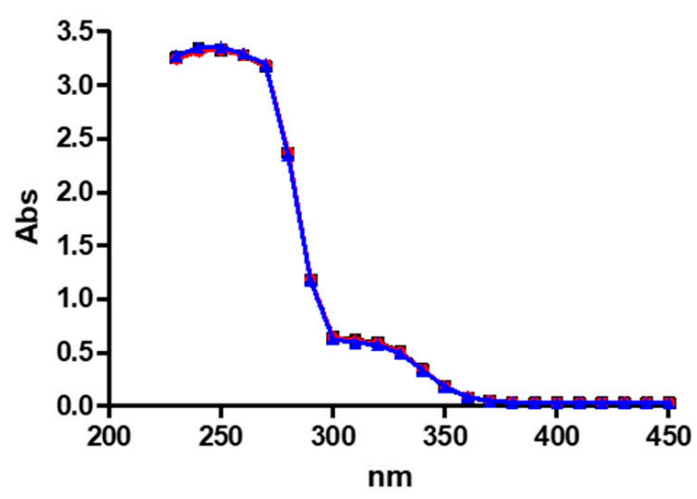

(A)
pH 7.4

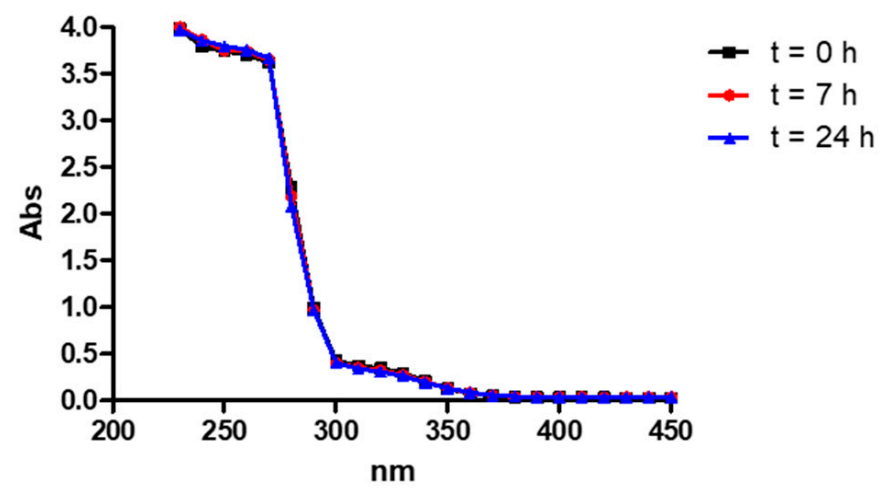

(B)

Figure 3. Time-dependent UV-Vis absorption spectra of compound L1 (A) and L1Pt (B) in PBS solution recorded after $\mathrm{t}=0 \mathrm{~h}$ (black line), $\mathrm{t}=7 \mathrm{~h}$ (red line), and $\mathrm{t}=24 \mathrm{~h}$ (blue line).

Table 3. Predicted binding energies of L1, L1Pt, and BTA on different DNA structures.

\begin{tabular}{cccc}
\hline \multicolumn{4}{c}{ Docking Binding Energy $(\mathbf{k c a l} / \mathbf{m o l})$} \\
\hline Name & 1BNA & 3CO3 & 1LU5 \\
\hline L1 & -6.697 & -5.839 & -4.636 \\
L1Pt & -7.150 & -5.695 & -4.164 \\
BTA & -6.658 & -6.495 & -5.037 \\
\hline
\end{tabular}

DNA intercalation and major or minor groove binding with DNA are the most frequently observed modes of interaction for small molecule drugs [48]. The molecular modeling results suggest that compounds L1 and L1Pt interacted with the minor groove of the DNA (PDB ID: IBNA) (Figure 4). The BTA fragment of these compounds fits into the minor groove of the DNA and interacts through its sulfur group by forming hydrogen bonds with the base pairs. In addition, the -NH group showed a hydrogen bond interaction with the DNA. The docked poses of the compound L1 and L1Pt (Figure 4) revealed that it binds to the minor groove of the DNA (PDB ID: 1BNA) using -6.697 and $-7.150 \mathrm{kcal} / \mathrm{mol}$ binding energy. Cisplatin requires hydration to form diaqua species, which are considered active agents. However, in this study, L1Pt remains stable over $24 \mathrm{~h}$ and probably does not palatinate the DNA (Figure 3), nevertheless it acts by intercalation. In contrast, ligand L1 showed groove binding intercalation with DNA and this can be one of the possible reasons for the higher cytotoxic effects than their corresponding Pt (II) complexes. The interactions of compound L1 and L1Pt with the 3CO3 and 1LU5 structures of the DNA are shown in the Supporting Information [Figures S15 and S16]. However, we must mention that the docking study alone is not sufficient to probe mechanism of action of compounds. To probe it, at least in vitro binding assays such as ITC and SPR should be carried out on DNA- model systems, as well as on protein models. Therefore, further study using in vitro binding assays is warranted to probe mechanism of action of compounds. 


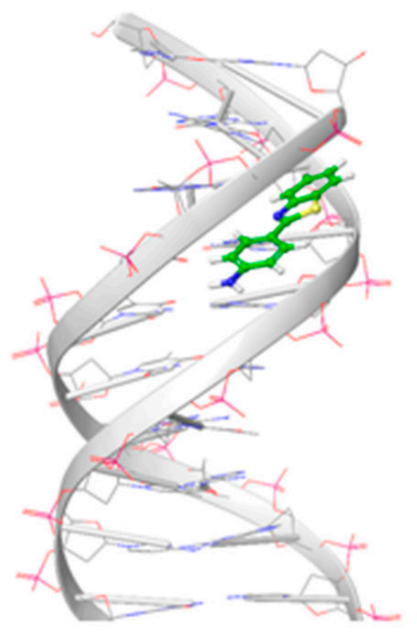

4 (A) IBNA-BTA

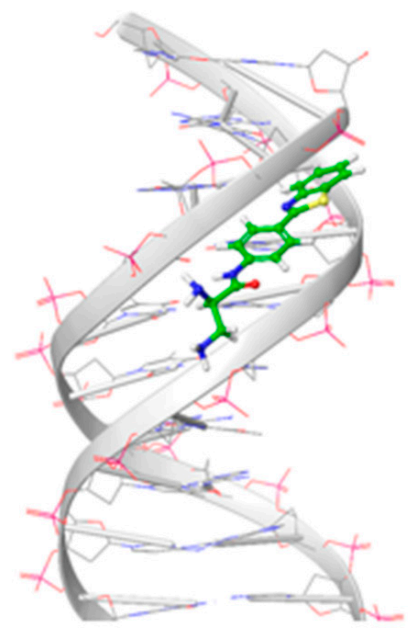

4 (B) IBNA-Ll

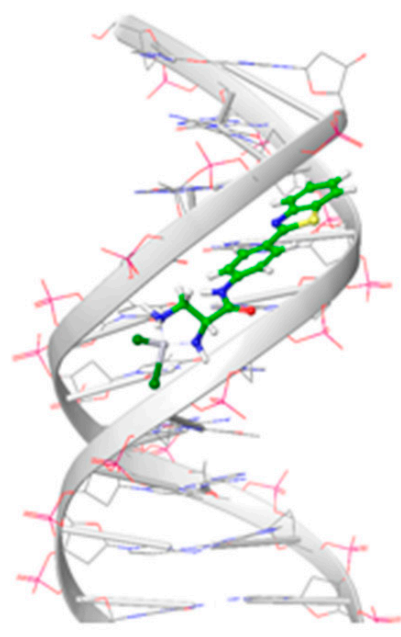

4 (C) IBNA-LIPt

Figure 4. (A) Predicted binding pose of BTA on DNA (PDB ID: 1BNA). (B) Molecular docking simulation studies of the interaction between L1 and DNA (PDB ID: 1BNA). (C) Molecular docking simulation studies of the interaction between L1Pt and DNA (PDB ID: 1BNA).

\section{Materials and Methods}

\subsection{Reagents and Instruments}

Solvents were dried using standard methods. 2,3-Diaminopropionic acid, di-tert-butyl dicarbonate $\left(\mathrm{Boc}_{2} \mathrm{O}\right)$, and triphenylphosphite $\left[\mathrm{P}\left(\mathrm{OC}_{6} \mathrm{H}_{5}\right)_{3}\right]$ were purchased from Tokyo Chemical Industry (Tokyo, Japan). Sodium bicarbonate $\left(\mathrm{NaHCO}_{3}\right)$ and potassium carbonate $\left(\mathrm{K}_{2} \mathrm{CO}_{3}\right)$ were purchased from Daejung Chem. (Siheung-si, Korea). Magnesium sulfate anhydrous $\left(\mathrm{MgSO}_{4}\right)$ and sodium sulfate anhydrous $\left(\mathrm{Na}_{2} \mathrm{SO}_{4}\right)$ were obtained from Duksan Scientific Corp. (Ansan-si, Korea). Salicylaldehyde was acquired from Junsei Chemical Co. Ltd. (Tokyo, Japan). 2-Pyridinecarboxaldehyde, 2-(4-aminophenyl)-benzothiazole, potassium tetra chloroplatinate (II) $\left(\mathrm{K}_{2} \mathrm{PtCl}_{4}\right)$, and other commercial-grade reagents were purchased from Sigma-Aldrich (St. Louis, MO, USA), and used as received, unless otherwise stated. Deionized water (DI water) was used for the experiments. Progress of chemical reactions was observed using TLC (silica gel plates $60 \mathrm{~F} 254$ ) and visualized using a UV-Vis spectrometer. ${ }^{1} \mathrm{H}-\mathrm{NMR}$ experiments were performed using an Advance 500 spectrometer (Bruker, Billerica, MA, USA) at the instrumental analysis center of Kyungpook National University (KNU, Daegu, Korea). Chemical shifts ( $\delta$ ) are reported in ppm and coupling constants $(J)$ in $\mathrm{Hz}$. FTIR spectra were recorded using $\mathrm{KBr}$ pellets on a model 883 double beam infrared spectrophotometer (PerkinElmer, Waltham, MA, USA) in $200-4000 \mathrm{~cm}^{-1}$. Microanalysis was performed using a CHNS elemental analyzer (Thermo Fisher Scientific, Waltham, MA, USA) at the KNU instrumental analysis center. HR-FAB-MS spectra were recorded using a model JMS-700 spectrophotometer (JEOL, Tokyo, Japan) at the Korea Basic Science Institute. Complexation reactions were conducted under an inert atmosphere using standard Schlenk techniques. The purity of the synthesized compounds was confirmed by EA and the tested compounds had at least 95\% purity.

\subsection{Synthesis and Characterization}

The syntheses of the benzothiazole aniline derivatives and their corresponding Pt (II) complexes are as follows:

\subsubsection{2,3-Diamino-N-(4-benzothiazol-2-yl-phenyl)-propionamide (L1)}

Compound L1 was synthesized according to the previously reported method [39]. 
3.2.2. N-(4-Benzothiazol-2-yl-phenyl)-2,3-bis-[(2-hydroxy-benzylidene)amino] propionamide (L2)

Salicylaldehyde $(0.42 \mathrm{~g}, 3.5 \mathrm{mmol})$ was added dropwise to compound $\mathbf{L 1}(0.54 \mathrm{~g}$, $1.7 \mathrm{mmol})$ dissolved in ethanol $(20 \mathrm{~mL})$. The resulting mixture was refluxed around $3 \mathrm{~h}$ until the starting materials disappeared. Solids that appeared were filtered and rinsed with a small portion of cold ethanol, and pure product was harvested as a white solid after resuspending in hexane. Yield: $0.42 \mathrm{~g}(48 \%) .{ }^{1} \mathrm{H}-\mathrm{NMR}\left(500 \mathrm{MHz}, \mathrm{CDCl}_{3}\right): \delta=12.8(s$, $2 \mathrm{H}, \mathrm{Ar}-\mathrm{OH}), 12.01(s, 1 \mathrm{H}, \mathrm{NH}), 8.45(s, 1 \mathrm{H}, \mathrm{CH}), 8.36(s, 1 \mathrm{H}, \mathrm{CH}), 8.07-8.01(m, 3 \mathrm{H}, \mathrm{BTA})$, 7.90-7.86 (d, 1H, BTA), 7.71-7.66 ( $d, 2 \mathrm{H}, \mathrm{BTA}), 7.49-7.44(t, 1 \mathrm{H}, \mathrm{BTA}), 7.41-7.38(t, 1 \mathrm{H}, \mathrm{BTA})$, 7.36-7.25 ( $m, 3 \mathrm{H}, \mathrm{Ar}-\mathrm{CH}), 7.22-7.18$ (d, 1H, Ar-CH), 7.04-6.81 ( $m, 4 \mathrm{H}, \mathrm{Ar}-\mathrm{CH}), 4.42-4.36(\mathrm{~m}$, $\left.2 \mathrm{H}, \mathrm{CH}_{2}\right), 4.09-3.03(\mathrm{~m}, 1 \mathrm{H}, \mathrm{CH})$. FTIR: v $\left(\mathrm{cm}^{-1}\right)=3299 \mathrm{w}, 1665 \mathrm{~s}, 1634(\mathrm{C}=\mathrm{N}) \mathrm{s}, 1524 \mathrm{~s}$, $1407 \mathrm{~m}, 1275 \mathrm{~m}, 967 \mathrm{~m}$, and $749 \mathrm{~m}$. HR-FAB-MS $(\mathrm{m} / \mathrm{z})$ for $\mathrm{C}_{30} \mathrm{H}_{24} \mathrm{~N}_{4} \mathrm{O}_{3} \mathrm{~S}$ : calcd, 521.1647 $[\mathrm{M}+\mathrm{H}]^{+}$; found, $521.1649[\mathrm{M}+\mathrm{H}]^{+}$. Anal. calcd for $\left(\mathrm{C}_{30} \mathrm{H}_{24} \mathrm{~N}_{4} \mathrm{O}_{3} \mathrm{~S} \cdot \frac{1}{2} \mathrm{H}_{2} \mathrm{O}\right): \mathrm{C}, 68.06 ; \mathrm{H}$, 4.76 ; N, 10.58; S, 6.06; found: $\mathrm{C}, 68.08 ; \mathrm{H}, 4.59 ; \mathrm{N}, 10.62 ; \mathrm{S}, 6.24$.

3.2.3. 2-Pyridin-2-yl-4,5-dihydro- $1 H$-imidazole-4-carboxylic acid (4-benzothiazol-2-yl-phenyl)amide (L3)

2-Pyridinecarboxaldehyde $(0.54 \mathrm{~mL}, 5.06 \mathrm{mmol})$ was added to a solution of compound $\mathbf{L 1}(1.58 \mathrm{~g}, 5.06 \mathrm{mmol})$ in dry tetrahydrofuran $(40 \mathrm{~mL})$ using an ice bath. NBromosuccinimide $(0.52 \mathrm{~g}, 2.94 \mathrm{mmol})$ in THF was added dropwise and stirred overnight at room temperature (RT). The resulting mixture was extracted using saturated $\mathrm{NaHCO}_{3}$ solution and washed with $\mathrm{CH}_{2} \mathrm{Cl}_{2}$. The collected organic layer was rinsed using saturated $\mathrm{NaCl}$ and dried over $\mathrm{Na}_{2} \mathrm{SO}_{4}$. After precipitation pure product was collected as a paleyellow solid. Yield: $0.7 \mathrm{~g}(36 \%) .{ }^{1} \mathrm{H}-\mathrm{NMR}\left(500 \mathrm{MHz}, \mathrm{CDCl}_{3}\right): \delta=9.82(s, 1 \mathrm{H}, \mathrm{NH}), 9.46(s$, $1 \mathrm{H}, \mathrm{NH}), 8.54$ (s, 1H, CH-Py), 8.33 (dd, 1H, CH-Py), 8.23 (s, 1H, C-Py), $7.81(m, 2 \mathrm{H}, \mathrm{BTA})$, $7.62(s, 1 \mathrm{H}, \mathrm{BTA}), 7.54(t, 3 \mathrm{H}, \mathrm{BTA}), 7.29-7.20(d d, 2 \mathrm{H}, \mathrm{BTA}), 7.06(t, 1 \mathrm{H}, \mathrm{CH}-\mathrm{Py}), 4.86(s, 1 \mathrm{H}$, $\mathrm{CH})$, 4.16-3.74 (d, 2H, $\left.\mathrm{CH}_{2}\right)$. Anal. Calcd for $\left(\mathrm{C}_{22} \mathrm{H}_{17} \mathrm{~N}_{5} \mathrm{OS} .1 .5 \mathrm{H}_{2} \mathrm{O}\right): \mathrm{C}, 61.98 ; \mathrm{H}, 4.71 ; \mathrm{N}$, 16.42; S, 7.52; found: C, 62.32; $\mathrm{H}, 3.98 ; \mathrm{N}, 15.64 ; \mathrm{S}, 7.54$. HR-FAB-MS $(\mathrm{m} / \mathrm{z})$ for $\mathrm{C}_{23} \mathrm{H}_{17} \mathrm{~N}_{5} \mathrm{OS}$ : Calcd, $400.1232[\mathrm{M}+\mathrm{H}]^{+}$; found: $400.1233[\mathrm{M}+\mathrm{H}]^{+}$.

\subsubsection{Synthesis of Complex L1Pt}

A solution of $\mathrm{K}_{2} \mathrm{PtCl}_{4}(0.14 \mathrm{~g}, 0.35 \mathrm{mmol})$ in distilled water $(10 \mathrm{~mL})$ was prepared under an inert atmosphere and added to compound $\mathbf{L 1}(0.11 \mathrm{~g}, 0.35 \mathrm{mmol})$. The resultant mixture was stirred overnight in the dark at RT. The precipitate obtained was filtered and rinsed using water, methanol, and ethyl ether. Vacuum drying produced a pale-yellow solid. A characteristic peak was observed at $-2754 \mathrm{ppm}$ corresponding to the $\mathrm{Pt}$ (II) species. Yield: $0.10 \mathrm{~g}(53 \%) .{ }^{1} \mathrm{H}-\mathrm{NMR}\left(500 \mathrm{MHz}, \mathrm{DMSO}_{6}\right): \delta=11.03(w, 1 \mathrm{H}, \mathrm{NH}), 8.77-8.51(w$, 2H, NH), 8.17-7.99 ( $m, 4 \mathrm{H}, \mathrm{BTA}), 7.92-7.80$ (d, 2H, BTA), 7.55 ( $t, 1 \mathrm{H}, \mathrm{BTA}), 7.46$ ( $(t, 1 \mathrm{H}, \mathrm{BTA})$, 6.62-6.20 (dd, 2H, NH $\left.\mathrm{NH}_{2}\right), 3.83(d d, 1 \mathrm{H}, \mathrm{CH}), 3.02-2.72\left(d d, 2 \mathrm{H}, \mathrm{CH}_{2}\right) .{ }^{195} \mathrm{Pt}-\mathrm{NMR}\left(\mathrm{DMSO}_{6}\right)$ : $\delta=-2754$. Anal. calcd for $\left(\mathrm{C}_{16} \mathrm{H}_{16} \mathrm{Cl}_{2} \mathrm{~N}_{4} \mathrm{OPtS} \cdot 2.5 \mathrm{H}_{2} \mathrm{O}\right): \mathrm{C}, 30.84 ; \mathrm{H}, 3.39 ; \mathrm{N}, 8.99 ; \mathrm{S}, 5.15$; found: C, 30.62; $\mathrm{H}, 2.81 ; \mathrm{N}, 8.74 ; \mathrm{S}, 5.20$. HR-FAB-MS $(\mathrm{m} / \mathrm{z})$ for $\mathrm{C}_{16} \mathrm{H}_{16} \mathrm{Cl}_{2} \mathrm{~N}_{4} \mathrm{OPtS}$ : calcd, $578.0148[\mathrm{M}+\mathrm{H}]^{+}$; found, $578.0144[\mathrm{M}+\mathrm{H}]^{+}$.

\subsubsection{Synthesis of Complex L2Pt}

Potassium carbonate $(0.19 \mathrm{~g}, 1.35 \mathrm{mmol})$ was added to a solution of ligand $\mathbf{L} 2(0.35 \mathrm{~g}$, $0.67 \mathrm{mmol})$ in DMF $(10 \mathrm{~mL})$. Next a solution of potassium tetrachloroplatinate $(0.28 \mathrm{~g}$, $0.67 \mathrm{mmol})$ in water $(10 \mathrm{~mL})$ was prepared under a stream of nitrogen and added to the mixture, which was then stirred overnight at a reaction temperature lower than $60{ }^{\circ} \mathrm{C}$. The reaction mixture was left to cool at RT and the solid was filtered. Pure compound was gathered as a pale-yellow solid following repeated flushing with water, methanol, and ethyl ether. Yield: $0.24 \mathrm{~g}(49 \%) .{ }^{1} \mathrm{H}-\mathrm{NMR}\left(500 \mathrm{MHz}, \mathrm{DMSO}-\mathrm{d}_{6}\right): \delta=10.75(s, 1 \mathrm{H}, \mathrm{NH})$, $8.76(s, 1 \mathrm{H}, \mathrm{Ar}-\mathrm{CH}), 8.60(\mathrm{~s}, 1 \mathrm{H}, \mathrm{Ar}-\mathrm{CH}), 8.17-7.78(\mathrm{~m}, 6 \mathrm{H}, \mathrm{BTA}), 7.69-7.37(d, 6 \mathrm{H}, \mathrm{Ar}-\mathrm{CH})$, $6.95(t, 1 \mathrm{H}, \mathrm{BTA}), 6.65(t, 1 \mathrm{H}, \mathrm{BTA}), 4.75(m, 1 \mathrm{H}, \mathrm{CH}), 4.32\left(d, 1 \mathrm{H}, \mathrm{CH}_{2}\right), 4.15\left(d, 1 \mathrm{H}, \mathrm{CH}_{2}\right)$, $2.09\left(\mathrm{~s}, 2 \mathrm{H}, \mathrm{NH}_{2}\right)$. FTIR: $\mathrm{v}\left(\mathrm{cm}^{-1}\right)=3054 \mathrm{w}, 1693 \mathrm{~s}, 1600 \mathrm{~s}(\mathrm{C}=\mathrm{N}), 1532 \mathrm{~s}, 1437 \mathrm{~m}, 1302 \mathrm{~m}$. 
Anal. calcd for $\left(\mathrm{C}_{30} \mathrm{H}_{22} \mathrm{~N}_{4} \mathrm{O}_{3} \mathrm{PtS} \cdot 2 \mathrm{H}_{2} \mathrm{O}\right)$ : $\mathrm{C}, 48.06 ; \mathrm{H}, 3.50 ; \mathrm{N}, 7.47 ; \mathrm{S}, 4.28$; found: $\mathrm{C}$, 48.10; $\mathrm{H}, 3.59$; N, 7.29; S, 6.87. HR-FAB-MS $(m / z)$ for $\mathrm{C}_{30} \mathrm{H}_{22} \mathrm{~N}_{4} \mathrm{O}_{3} \mathrm{PtS}$ : calcd, $714.1139[\mathrm{M}+\mathrm{H}]^{+}$; found, $714.1142[\mathrm{M}+\mathrm{H}]^{+}$.

\subsubsection{Synthesis of Complex L3Pt}

A solution of $\mathrm{K}_{2} \mathrm{PtCl}_{4}(0.45 \mathrm{~g}, 1.10 \mathrm{mmol})$ in distilled water $(15 \mathrm{~mL})$ was prepared under a stream of nitrogen and added to a solution of ligand $\mathbf{L 3}(0.4 \mathrm{~g}, 1.10 \mathrm{mmol})$ in ethanol $(15 \mathrm{~mL})$. The resultant mixture was stirred in the dark under a nitrogen atmosphere at $50^{\circ} \mathrm{C}$, overnight. Solid that appeared was filtered and the pale-yellow product harvested after repeated washing using water, ethanol, and $\mathrm{Et}_{2} \mathrm{O}$. Yield: $0.27 \mathrm{~g}(39 \%) .{ }^{1} \mathrm{H}-\mathrm{NMR}(500 \mathrm{MHz}$, DMSO- $\left.\mathrm{d}_{6}\right): \delta=8.17-7.98(m, 6 \mathrm{H}, \mathrm{BTA}), 7.86(t, 1 \mathrm{H}, \mathrm{BTA}), 7.82(t, 1 \mathrm{H}, \mathrm{BTA}), 7.57-7.42(m, 4 \mathrm{H}$, Py), $5.04(t, 1 \mathrm{H}, \mathrm{CH}), 4.56-3.98\left(m, 2 \mathrm{H}, \mathrm{CH}_{2}\right)$. Anal. calcd for $\left(\mathrm{C}_{22} \mathrm{H}_{17} \mathrm{Cl}_{2} \mathrm{~N}_{5} \mathrm{OPtS} \cdot 2 \mathrm{H}_{2} \mathrm{O}\right): \mathrm{C}$, 37.67; H, 3.02; N, 9.98; S, 4.57; found: C, 37.81; H, 2.71; N, 8.97; S, 3.57. HR-MS ( $\mathrm{m} / \mathrm{z})$ for $\mathrm{C}_{22} \mathrm{H}_{17} \mathrm{Cl}_{2} \mathrm{~N}_{5} \mathrm{OPtS}$ : calcd, $687.0076[\mathrm{M}+\mathrm{Na}]^{+}$; found, $687.2321[\mathrm{M}+\mathrm{Na}]^{+}$.

\subsection{Stability of the Compounds in Aqueous Solution}

The stability of the most active compounds, L1 and L1Pt, was studied. The compounds, L1 and L1Pt, at a concentration of $1 \mathrm{mM}$ in phosphate-buffered saline (PBS) solution at different $\mathrm{pH}$-values [(e.g., strong acidic $(\mathrm{pH}=2)$, weakly acidic $(\mathrm{pH}=5)$, neutral $(\mathrm{pH}=7.4)$, alkaline $(\mathrm{pH}=12)]$ were evaluated using UV-Vis spectroscopy. In the case of L1Pt, 2\% DMSO in PBS was used as solvent due to the poor water solubility. The spectra were recorded in the range of $200-450 \mathrm{~nm}$ at $\mathrm{t}=0,7$, and $24 \mathrm{~h}$, and compared to each other.

\subsection{Cell Culture}

Human colorectal adenocarcinoma cells (HT-29, ATCC ${ }^{\circledR}$ HTB-38), adenocarcinomic human alveolar basal epithelial cells (A549, ATCC ${ }^{\circledR}$ CCL-185), and prostate cancer (PC-3, ATCC ${ }^{\circledR}$ CRL-1435) were cultured in the growth medium, containing Roswell Park Memorial Institute Medium (RPMI1640) WelGENE, Daegu, Korea supplemented with 10\% (v/v) fetal bovine serum (FBS, Gibco, Grand Island, NY, USA) and 1\% antibiotics-antimycotics (Gibco). Human breast adenocarcinoma cells (MCF-7, ATCC ${ }^{\circledR}$ HTB-22 ${ }^{\mathrm{TM}}$ ), hepatocellular carcinoma (HepG2, ATCC ${ }^{\circledR}$ HB-8065 $\left.{ }^{\mathrm{TM}}\right)$, Rattus brain glioma (C6, ATCC ${ }^{\circledR}$ CRL-2303 ${ }^{\mathrm{TM}}$ ), and human renal carcinoma (Caki-2, ATCC ${ }^{\circledR}$ HTB-47 ${ }^{\mathrm{TM}}$ ) cells were cultured in Dulbecco's modified Eagle's medium (DMEM, WelGENE, Daegu, Korea) supplemented with 10\% $(v / v)$ FBS (Gibco) and 1\% antibiotics-antimycotics (Gibco). Mouse brain neural (NE-4C, ATCC ${ }^{\circledR}$ CRL-2925 ${ }^{\mathrm{TM}}$ ) and human cervix adenocarcinoma cells (HeLa, ATCC ${ }^{\circledR}$ CCL-2 ${ }^{\mathrm{TM}}$ ) were cultured in Eagle's minimum essential medium (EMEM, ATCC ${ }^{\circledR} 30-2003^{\mathrm{TM}}$ ) supplemented with 10\% FBS (Gibco) and 1\% antibiotics-antimycotics (Gibco). Mouse liver normal cells (AML12, ATCC ${ }^{\circledR}$ CRL-2254 ${ }^{\mathrm{TM}}$ ) were cultured in DMEM/F-12 (WelGENE) supplemented with $10 \%$ FBS (Gibco), $1 \times$ ITS $(10 \mu \mathrm{g} / \mathrm{mL}$ insulin, $5.5 \mu \mathrm{g} / \mathrm{mL}$ transferrin, $6.7 \mathrm{ng} / \mathrm{mL}$ selenium, Gibco), $40 \mathrm{ng}$ minimum essential medium Eagle (WelGENE) supplemented with 10\% FBS (Gibco, USA) and 1\% antibiotics-antimycotics (Gibco). Human breast epithelial cells (MCF 10A, ATCC ${ }^{\circledR}$ CRL-10317 mented with $5 \%$ horse serum (Gibco), $20 \mathrm{ng} / \mathrm{mL}$ epidermal growth factor (EGF, Peprotech Inc., Rocky Hill, NJ, USA), $500 \mu \mathrm{g} / \mathrm{mL}$ hydrocortisone (Sigma-Aldrich, St. Louis, MO, USA), $100 \mathrm{ng} / \mathrm{mL}$ colera toxin (Sigma-Aldrich), $10 \mu \mathrm{g} / \mathrm{mL}$ insulin (Sigma-Aldrich) and $1 \%$ antibiotics- (Gibco). Human colon normal epithelial cells (FHC, ATCC ${ }^{\circledR}$ CRL-18317 ${ }^{\mathrm{TM}}$ ) were cultured in DMEM/F-12 (WelGENE) supplemented with 10\% FBS (Gibco), $10 \mathrm{ng} / \mathrm{mL}$ cholera toxin (Sigma-Aldrich), $20 \mathrm{ng} / \mathrm{mL}$ EGF (Peprotech Inc.), $100 \mu \mathrm{g} / \mathrm{mL}$ hydrocortisone (Sigma-Aldrich), $1 \times$ ITS $(10 \mu \mathrm{g} / \mathrm{mL}$ insulin, $5.5 \mu \mathrm{g} / \mathrm{mL}$ transferrin, $6.7 \mathrm{ng} / \mathrm{mL}$ selenium, Gibco) and 1\% antibiotics-antimycotics (with 100 units penicillin, $100 \mu \mathrm{g}$ streptomycin and $250 \mathrm{ng}$ amphotericin $\mathrm{B}$ per $\mathrm{mL}$, Gibco). Cells were incubated in a humidified $5 \% \mathrm{CO}_{2}$ atmosphere at $37^{\circ} \mathrm{C}$. 


\subsection{Cell Viability Assay}

To evaluate cytotoxicity, cells were seeded in a 96-well plate (FHC, $0.5 \times 10^{4}$ cells/well; Caki-2 and MCF 10A, $1 \times 10^{4}$ cells/well; AML12, $1.2 \times 10^{4}$ cells/well; HeLa, HEK-293, A549, and PC-3, $1.5 \times 10^{4}$ cells/well; HT-29, MCF-7, C6, HepG2, and NE-4C, $2 \times 10^{4}$ cells/well). After attaching and stabilizing cells for $24 \mathrm{~h}$, the medium was switched to various concentrations $(0,2.5,5,10,20,30,40,50,100$, and $200 \mu \mathrm{M})$ of cisplatin (Sigma-Aldrich), BTA (Sigma-Aldrich), L1, L1Pt, L2, L2Pt, L3, and L3Pt, and cells were incubated for $22 \mathrm{~h}$. In addition, cell counting kit-8 (CCK-8, Dojindo Laboratories, Kumamoto, Japan) solution was added to each well, and the plate was incubated for $2 \mathrm{~h}$. The absorbance was then measured at $450 \mathrm{~nm}$ using a microplate reader (SpectraMax i3, Molecular Devices, San Jose, CA, USA). The $\mathrm{IC}_{50}$ and $\log \mathrm{IC}_{50}$ values were calculated in GraphPad Prism (GraphPad Prism Software Inc. Version 5.02, San Diego, CA, USA). All experiments were performed, independently, three times. The graph of $\log \mathrm{IC}_{50}$ values represents the average value.

\subsection{Molecular Docking}

Binding poses and energies of L1, L1Pt, and BTA for DNA structures were predicted using a protein-ligand docking simulation application called Glide [49]. Glide searches for possible binding poses of given ligands on DNA structure surface and finds the best binding poses and energy using the empirical scoring function called GlideScore [49]. For docking simulation, the OPLS3 force field was used to describe the atomic forces of ligand and DNA molecules. Flexible ligand sampling of ligand was allowed and the standard precision mode of Glide was used.

\subsection{Statistical Analysis}

Data were evaluated using a one-way analysis of variance with Tukey's multiple comparison tests. Analyses were performed using GraphPad Prism (GraphPad Prism Software Inc., version 5.02). Data are expressed as mean \pm SD (standard deviation) or standard error of the mean values, and $p<0.05$ was considered significant, statistically.

\section{Conclusions}

In this study, three novel benzothiazole aniline derivatives L1, L2, and L3 and their corresponding Pt (II) complexes L1Pt, L2Pt, and L3Pt have been designed and synthesized. The targeted compounds were investigated for their in vitro cytotoxic activity using the CCK-8 assay against various cancer and normal cells lines. Compared to the parental BTA and clinically used cisplatin, compounds L1, and L1Pt demonstrated selective inhibitory activities against liver cancer cells. In addition, docking results indicate that compounds L1 and L1Pt interact with the minor groove of the DNA, and remain stable in aqueous media. Therefore, these compounds may be considered as prospective alternatives to the present chemotherapy drugs.

Supplementary Materials: The following are available online at https:/ / www.mdpi.com/article/ 10.3390/ph14080832/s1, Content: Figure S1: ${ }^{1} \mathrm{H}-\mathrm{NMR}$ spectrum of compound L2, Figure S2: High resolution-FAB- mass spectrum of compound L2, Figure S3: FTIR spectrum of compound L2, Figure S4: ${ }^{1} \mathrm{H}-\mathrm{NMR}$ spectrum of compound L3, Figure S5: High resolution-FAB- mass spectrum of compound L3, Figure S6: ${ }^{1} \mathrm{H}-\mathrm{NMR}$ spectrum of compound L1Pt, Figure S7: ${ }^{195} \mathrm{Pt}-\mathrm{NMR}$ spectrum of compound L1Pt, Figure S8: High resolution-FAB- mass spectrum of compound L1Pt, Figure S9: ${ }^{1} \mathrm{H}-$ NMR spectrum of compound L2Pt, Figure S10: FTIR spectrum of compound L2Pt, Figure S11: High resolution-FAB- mass spectrum of compound L2Pt, Figure S12: ${ }^{1} \mathrm{H}-\mathrm{NMR}$ spectrum of compound L3Pt, Figure S13: MALDI-TOF mass spectrum of compound L3Pt, Figure S14. Time-dependent UV-Vis absorption spectra of L1 and L1Pt. Figure S15: Molecular docking of BTA, L1, and L1Pt with DNA, Figure S16: Molecular docking of BTA, L1, and L1Pt with DNA. 
Author Contributions: Conceptualization, Y.C., H.-K.K. and M.K.I.; methodology, M.K.I., A.-R.B. and B.S.; validation, B.-W.Y., G.C. and H.-J.P.; formal analysis, Y.-H.K., M.K. and G.-H.L.; writingoriginal draft preparation, M.K.I. and Y.C.; investigation, H.-K.K. and S.H.; supervision, Y.C. and H.-K.K.; project administration, Y.C.; funding acquisition, Y.C. and G.-H.L. All authors have read and agreed to the published version of the manuscript.

Funding: This work was supported by the National Research Foundation (NRF) grant funded by the Korean government (Ministry of Science, Information and Communications Technology: MSIT). Grants no. 2021R1A4A1029433.

Institutional Review Board Statement: Not applicable.

Informed Consent Statement: Not applicable.

Data Availability Statement: Data is contained within the article and supplementary files.

Conflicts of Interest: The authors declare no conflict of interest.

\begin{tabular}{ll}
\multicolumn{2}{l}{ Abbreviations } \\
BTA & Benzothiazole aniline \\
RT & Room temperature \\
CCK-8 & Cell counting kit-8 \\
DNA & Deoxyribonucleic acid \\
DI & Deionized \\
SAR & Structure-activity relationship \\
FTIR & Fourier-transform infrared spectroscopy \\
MALDI-TOF & Matrix-assisted laser desorption/ionization time-of-flight mass spectrometry \\
PBS & Phosphate-buffered solution \\
UV & Ultraviolet \\
DMSO & Dimethyl sulfoxide \\
NMR & Nuclear magnetic resonance
\end{tabular}

\section{References}

1. Olszewski, U.; Hamilton, G. A better platinum-based anticancer drug yet to come? Anti Cancer Agents Med. Chem. Former. Curr. Med. Chem. Anti Cancer Agents 2010, 10, 293-301. [CrossRef] [PubMed]

2. Johnstone, T.C.; Suntharalingam, K.; Lippard, S.J. The next generation of platinum drugs: Targeted Pt (II) agents, nanoparticle delivery, and Pt (IV) prodrugs. Chem. Rev. 2016, 116, 3436-3486. [CrossRef]

3. Bellamy, W.T. P-glycoproteins and multidrug resistance. Annu. Rev. Pharmacol. Toxicol. 1996, 36, 161-183. [CrossRef] [PubMed]

4. Todd, R.C.; Lippard, S.J. Inhibition of transcription by platinum antitumor compounds. Metallomics 2009, 1, 280-291. [CrossRef]

5. Wang, D.; Lippard, S.J. Cellular processing of platinum anticancer drugs. Nat. Rev. Drug Discov. 2005, 4, 307-320. [CrossRef]

6. Usanova, S.; Piee-Staffa, A.; Sied, U.; Thomale, J.; Schneider, A.; Kaina, B.; Koberle, B. Cisplatin sensitivity of testis tumour cells is due to deficiency in interstrand-crosslink repair and low ERCC1-XPF expression. Mol. Cancer 2010, 9, 248. [CrossRef]

7. Sakai, W.; Swisher, E.M.; Karlan, B.Y.; Agarwal, M.K.; Higgins, J.; Friedman, C.; Villegas, E.; Jacquemont, C.; Farrugia, D.J.; Couch, F.J.; et al. Secondary mutations as a mechanism of cisplatin resistance in BRCA2-mutated cancers. Nature 2008, 451, 1116-1120. [CrossRef] [PubMed]

8. Dempke, W.; Voigt, W.; Grothey, A.; Hill, B.T.; Schmoll, H.J. Cisplatin resistance and oncogenes-A review. Anticancer Drugs 2000, 11, 225-236. [CrossRef] [PubMed]

9. McWhinney, S.R.; Goldberg, R.M.; McLeod, H.L. Platinum neurotoxicity pharmacogenetics. Mol. Cancer Ther. 2009, 8, 10-16. [CrossRef]

10. Min, Y.; Mao, C.Q.; Chen, S.; Ma, G.; Wang, J.; Liu, Y. Combating the drug resistance of cisplatin using a platinum prodrug based delivery system. Angew. Chem. Int. Ed. Engl. 2012, 51, 6742-6747. [CrossRef]

11. Cohen, S.M.; Lippard, S.J. Cisplatin: From DNA damage to cancer chemotherapy. Prog. Nucleic Acid Res. Mol. Biol. 2001, 67, 93-130.

12. Wheate, N.J.; Walker, S.; Craig, G.E.; Oun, R. The status of platinum anticancer drugs in the clinic and in clinical trials. Dalton Trans. 2010, 39, 8113-8127. [CrossRef] [PubMed]

13. Chovanec, M.; Abu Zaid, M.; Hanna, N.; El-Kouri, N.; Einhorn, L.H.; Albany, C. Long-term toxicity of cisplatin in germ-cell tumor survivors. Ann. Oncol. 2017, 28, 2670-2679. [CrossRef] [PubMed]

14. Kelland, L. The resurgence of platinum-based cancer chemotherapy. Nat. Rev. Cancer 2007, 7, 573. [CrossRef] [PubMed]

15. Burger, H.; Loos, W.J.; Eechoute, K.; Verweij, J.; Mathijssen, R.H.; Wiemer, E.A. Drug transporters of platinum-based anticancer agents and their clinical significance. Drug Resist. Updates 2011, 14, 22-34. [CrossRef] [PubMed]

16. Chen, S.-H.; Chang, J.-Y. New insights into mechanisms of cisplatin resistance: From tumor cell to microenvironment. Int. J. Mol. Sci. 2019, 20, 4136. [CrossRef] 
17. Cincinelli, R.; Musso, L.; Dallavalle, S.; Artali, R.; Tinelli, S.; Colangelo, D.; Zunino, F.; De Cesare, M.; Beretta, G.L.; Zaffaroni, N. Design, modeling, synthesis and biological activity evaluation of camptothecin-linked platinum anticancer agents. Eur. J. Med. Chem. 2013, 63, 387-400. [CrossRef]

18. Lovejoy, K.S.; Todd, R.C.; Zhang, S.; McCormick, M.S.; D’Aquino, J.A.; Reardon, J.T.; Sancar, A.; Giacomini, K.M.; Lippard, S.J. cis-Diammine(pyridine)chloroplatinum(II), a monofunctional platinum(II) antitumor agent: Uptake, structure, function, and prospects. Proc. Natl. Acad. Sci. USA 2008, 105, 8902-8907. [CrossRef]

19. Yellol, G.S.; Donaire, A.; Yellol, J.G.; Vasylyeva, V.; Janiak, C.; Ruiz, J. On the antitumor properties of novel cyclometalated benzimidazole $\mathrm{Ru}(\mathrm{II}), \mathrm{Ir}(\mathrm{III})$ and $\mathrm{Rh}(\mathrm{III})$ complexes. Chem. Commun. (Camb.) 2013, 49, 11533-11535. [CrossRef]

20. Shi, D.-F.; Bradshaw, T.D.; Wrigley, S.; McCall, C.J.; Lelieveld, P.; Fichtner, I.; Stevens, M.F. Antitumor benzothiazoles. 3. Synthesis of 2-(4-aminophenyl) benzothiazoles and evaluation of their activities against breast cancer cell lines in vitro and in vivo. J. Med. Chem. 1996, 39, 3375-3384. [CrossRef]

21. Bradshaw, T.; Wrigley, S.; Shi, D.; Schultz, R.; Paull, K.; Stevens, M. 2-(4-Aminophenyl) benzothiazoles: Novel agents with selective profiles of in vitro anti-tumour activity. Br. J. Cancer 1998, 77, 745. [CrossRef]

22. Bradshaw, T.; Shi, D.; Schultz, R.; Paull, K.; Kelland, L.; Wilson, A.; Garner, C.; Fiebig, H.; Wrigley, S.; Stevens, M. Influence of 2-(4-aminophenyl) benzothiazoles on growth of human ovarian carcinoma cells in vitro and in vivo. Br. J. Cancer 1998, 78, 421 . [CrossRef]

23. Leong, C.-O.; Gaskell, M.; Martin, E.; Heydon, R.; Farmer, P.; Bibby, M.; Cooper, P.; Double, J.; Bradshaw, T.; Stevens, M. Antitumour 2-(4-aminophenyl) benzothiazoles generate DNA adducts in sensitive tumour cells in vitro and in vivo. Br. J. Cancer 2003, 88, 470-477. [CrossRef] [PubMed]

24. Bradshaw, T.; Stevens, M.; Westwell, A. The discovery of the potent and selective antitumour agent 2-(4-amino-3-methylphenyl) benzothiazole (DF 203) and related compounds. Curr. Med. Chem. 2001, 8, 203-210. [CrossRef] [PubMed]

25. Bradshaw, T.; Westwell, A. The development of the antitumour benzothiazole prodrug, Phortress, as a clinical candidate. Curr. Med. Chem. 2004, 11, 1009-1021. [CrossRef] [PubMed]

26. Kashiyama, E.; Hutchinson, I.; Chua, M.-S.; Stinson, S.F.; Phillips, L.R.; Kaur, G.; Sausville, E.A.; Bradshaw, T.D.; Westwell, A.D.; Stevens, M.F. Antitumor benzothiazoles. 8. Synthesis, metabolic formation, and biological properties of the C-and N-oxidation products of antitumor 2-(4-aminophenyl) benzothiazoles. J. Med. Chem. 1999, 42, 4172-4184. [CrossRef]

27. Noolvi, M.N.; Patel, H.M.; Kaur, M. Benzothiazoles: Search for anticancer agents. Eur. J. Med. Chem. 2012, 54, 447-462. [CrossRef] [PubMed]

28. Zhang, Y.; Chakraborty, M.; Cerda-Smith, C.G.; Bratton, R.N.; Maurer, N.E.; Senser, E.M.; Novak, M. Chemistry of RingSubstituted 4-(Benzothiazol-2-yl) phenylnitrenium Ions from Antitumor 2-(4-Aminophenyl) benzothiazoles. J. Org. Chem. 2013, 78, 6992-7000. [CrossRef]

29. Tzanopoulou, S.; Pirmettis, I.C.; Patsis, G.; Paravatou-Petsotas, M.; Livaniou, E.; Papadopoulos, M.; Pelecanou, M. Synthesis, characterization, and biological evaluation of $\mathrm{M}(\mathrm{I})(\mathrm{CO}) 3(\mathrm{NNO})$ complexes $(\mathrm{M}=\mathrm{Re}, 99 \mathrm{mTc})$ conjugated to 2-(4-aminophenyl) benzothiazole as potential breast cancer radiopharmaceuticals. J. Med. Chem. 2006, 49, 5408-5410. [CrossRef]

30. Tzanopoulou, S.; Sagnou, M.; Paravatou-Petsotas, M.; Gourni, E.; Loudos, G.; Xanthopoulos, S.; Lafkas, D.; Kiaris, H.; Varvarigou, A.; Pirmettis, I.C. Evaluation of Re and 99mTc complexes of 2-(4'-aminophenyl) benzothiazole as potential breast cancer radiopharmaceuticals. J. Med. Chem. 2010, 53, 4633-4641. [CrossRef]

31. Kim, H.-K.; Kang, M.-K.; Jung, K.-H.; Kang, S.-H.; Kim, Y.-H.; Jung, J.-C.; Lee, G.H.; Chang, Y.; Kim, T.-J. Gadolinium complex of DO3A-benzothiazole aniline (BTA) conjugate as a theranostic agent. J. Med. Chem. 2013, 56, 8104-8111. [CrossRef]

32. Mavroidi, B.; Sagnou, M.; Stamatakis, K.; Paravatou-Petsotas, M.; Pelecanou, M.; Methenitis, C. Palladium (II) and platinum (II) complexes of derivatives of 2-(4'-aminophenyl) benzothiazole as potential anticancer agents. Inorg. Chim. Acta 2016, 444, 63-75. [CrossRef]

33. Sagasser, J.; Ma, B.N.; Baecker, D.; Salcher, S.; Hermann, M.; Lamprecht, J.; Angerer, S.; Obexer, P.; Kircher, B.; Gust, R. A New Approach in Cancer Treatment: Discovery of Chlorido[ $\mathrm{N}, \mathrm{N}^{\prime}$-disalicylidene-1,2-phenylenediamine]iron(III) Complexes as Ferroptosis Inducers. J. Med. Chem. 2019, 62, 8053-8061. [CrossRef]

34. Li, Y.S.; Peng, B.; Ma, L.; Cao, S.L.; Bai, L.L.; Yang, C.R.; Wan, C.Q.; Yan, H.J.; Ding, P.P.; Li, Z.F.; et al. Synthesis, crystal structures and antitumor activity of two platinum(II) complexes with methyl hydrazinecarbodithioate derivatives of indolin-2-one. Eur. J. Med. Chem. 2017, 127, 137-146. [CrossRef] [PubMed]

35. Tomczyk, M.D.; Walczak, K.Z. 1,8-Naphthalimide based DNA intercalators and anticancer agents. A systematic review from 2007 to 2017. Eur. J. Med. Chem. 2018, 159, 393-422. [CrossRef] [PubMed]

36. Weninger, A.; Baecker, D.; Obermoser, V.; Egger, D.; Wurst, K.; Gust, R. Synthesis and Biological Evaluation of Zeise's Salt Derivatives with Acetylsalicylic Acid Substructure. Int. J. Mol. Sci. 2018, 19, 1612. [CrossRef]

37. Intini, F.P.; Zajac, J.; Novohradsky, V.; Saltarella, T.; Pacifico, C.; Brabec, V.; Natile, G.; Kasparkova, J. Novel Antitumor Platinum(II) Conjugates Containing the Nonsteroidal Anti-inflammatory Agent Diclofenac: Synthesis and Dual Mechanisms of Antiproliferative Effects. Inorg. Chem. 2017, 56, 1483-1497. [CrossRef]

38. Herrera, J.M.; Mendes, F.; Gama, S.; Santos, I.; Navarro Ranninger, C.; Cabrera, S.; Quiroga, A.G. Design and biological evaluation of new platinum(II) complexes bearing ligands with DNA-targeting ability. Inorg. Chem. 2014, 53, 12627-12634. [CrossRef] 
39. Islam, M.K.; Kim, S.; Kim, H.-K.; Park, S.; Lee, G.-H.; Kang, H.J.; Jung, J.-C.; Park, J.-S.; Kim, T.-J.; Chang, Y. Manganese Complex of Ethylenediaminetetraacetic Acid (EDTA)-Benzothiazole Aniline (BTA) Conjugate as a Potential Liver-Targeting MRI Contrast Agent. J. Med. Chem. 2017, 60, 2993-3001. [CrossRef]

40. Still, B.M.; Kumar, P.G.; Aldrich-Wright, J.R.; Price, W.S. 195Pt NMR-theory and application. Chem. Soc. Rev. 2007, 36, 665-686. [CrossRef]

41. Hille, A.; Ott, I.; Kitanovic, A.; Kitanovic, I.; Alborzinia, H.; Lederer, E.; Wolfl, S.; Metzler-Nolte, N.; Schafer, S.; Sheldrick, W.S.; et al. [N,N'-Bis(salicylidene)-1,2-phenylenediamine]metal complexes with cell death promoting properties. J. Biol. Inorg. Chem. 2009, 14, 711-725. [CrossRef]

42. Lenis-Rojas, O.A.; Robalo, M.P.; Tomaz, A.I.; Carvalho, A.; Fernandes, A.R.; Marques, F.; Folgueira, M.; Yanez, J.; Vazquez-Garcia, D.; Lopez Torres, M.; et al. Ru(II)( p-cymene) Compounds as Effective and Selective Anticancer Candidates with No Toxicity in Vivo. Inorg. Chem. 2018, 57, 13150-13166. [CrossRef]

43. Fennelly, C.; Amaravadi, R.K. Lysosomal Biology in Cancer. Methods Mol. Biol. 2017, 1594, $293-308$.

44. Grazul, M.; Besic-Gyenge, E.; Maake, C.; Ciolkowski, M.; Czyz, M.; Sigel, R.K.; Budzisz, E. Synthesis, physico-chemical properties and biological analysis of newly obtained copper(II) complexes with pyrazole derivatives. J. Inorg. Biochem. 2014, 135, 68-76. [CrossRef] [PubMed]

45. Tan, C.; Hu, S.; Liu, J.; Ji, L. Synthesis, characterization, antiproliferative and anti-metastatic properties of two ruthenium-DMSO complexes containing 2,2'-biimidazole. Eur. J. Med. Chem. 2011, 46, 1555-1563. [CrossRef] [PubMed]

46. Fereidoonnezhad, M.; Niazi, M.; Ahmadipour, Z.; Mirzaee, T.; Faghih, Z.; Faghih, Z.; Shahsavari, H.R. Cyclometalated Platinum(II) Complexes Comprising 2-(Diphenylphosphino)pyridine and Various Thiolate Ligands: Synthesis, Spectroscopic Characterization, and Biological Activity. Eur. J. Inorg. Chem. 2017, 2017, 2247-2254. [CrossRef]

47. Fereidoonnezhad, M.; Niazi, M.; Shahmohammadi Beni, M.; Mohammadi, S.; Faghih, Z.; Faghih, Z.; Shahsavari, H.R. Synthesis, Biological Evaluation, and Molecular Docking Studies on the DNA Binding Interactions of Platinum(II) Rollover Complexes Containing Phosphorus Donor Ligands. ChemMedChem 2017, 12, 456-465. [CrossRef]

48. Fereidoonnezhad, M.; Faghih, Z.; Mojaddami, A.; Tabaei, S.M.H.; Rezaei, Z. Novel Approach Synthesis, Molecular Docking and Cytotoxic Activity Evaluation of N-phenyl-2,2-dichloroacetamide Derivatives as Anticancer Agents. J. Sci. Islamic Repub. Iran 2016, 27, 39-49.

49. Schrödinger Release 2021-3, Glide; Schrödinger, LLC: New York, NY, USA, 2021. 